\title{
Aging human body: changes in bone, muscle and body fat with consequent changes in nutrient intake
}

\author{
Pegah JafariNasabian', Julia E Inglis', Wendimere Reilly', Owen J Kelly² and \\ Jasminka Z Ilich'1 \\ 1Department of Nutrition, Food and Exercise Sciences, Florida State University, Tallahassee, Florida, USA \\ ${ }^{2}$ Abbott Nutrition, Columbus, Ohio, USA
}

Correspondence should be addressed to J Z Ilich

Email

jilichernst@fsu.edu

\begin{abstract}
Aging affects almost all physiological processes, but changes in body composition and body phenotype are most observable. In this review, we focus on these changes, including loss of bone and muscle and increase in body fat or redistribution of the latter, possibly leading to osteosarcopenic obesity syndrome. We also address low-grade chronic inflammation, prevalent in aging adults and a cause of many disorders including those associated with body composition. Changes in dietary intake and nutritional requirements of older individuals, that all may lead to some disturbances on tissue and organ levels, are discussed as well. Finally, we discuss the hormonal changes in the aging body, considering each of the tissues, bone, muscle and fat as separate endocrine organs, but yet in the continuous interface and communication with each other.

Although there are still many unanswered questions in this field, this review will enable the readers to better understand the aging human body and measures needing to be implemented toward reducing impaired health and disability in older individuals.
\end{abstract}

\author{
Key Words \\ - aging \\ - body composition \\ - nutrition \\ - osteosarcopenic obesity
}

\section{Introduction}

As a result of increased life expectancy, the demographics of aging is rapidly changing. Accordingly, it is predicted that the number of people older than 65 years in the United States will double by 2030, reaching approximately 70 million or about $20 \%$ of total population (Ortman et al. 2014). This increased number of older individuals might lead to the epidemic of certain diseases typical for elderly, like osteoporosis, type II diabetes, cardiovascular diseases and various cancers (Hughes et al. 2001, Kalyani et al. 2014, Hita-Contreras et al. 2015). Among many physiological changes occurring with aging, the most notable are decrease in cardiac output at rest, maximum breathing capacity, renal filtration rate and nerve conduction velocity (McClaran et al. 1995, Glassock \& Winearls 2009,
Strait \& Lakatta 2012). Additionally, dehydration caused by decreased nocturnal antidiuretic hormone secretion, as well as the limited access to fluid due to various reasons (Frangeskou et al. 2015), may result in multiple health and economic consequences leading to increased utilization of hospital intensive care units and higher readmission rates to short- and long-term care facilities (Frangeskou et al. 2015). Furthermore, it is also important to note that low-grade chronic inflammation (LGCI) increases with age and persists in older individuals, even when other illnesses are not present (Ilich et al. 2014a). As recently reviewed, both dietary factors and lifestyle influences may contribute to LGCI and subsequent worsening of many chronic diseases, including osteoporosis and obesity. 


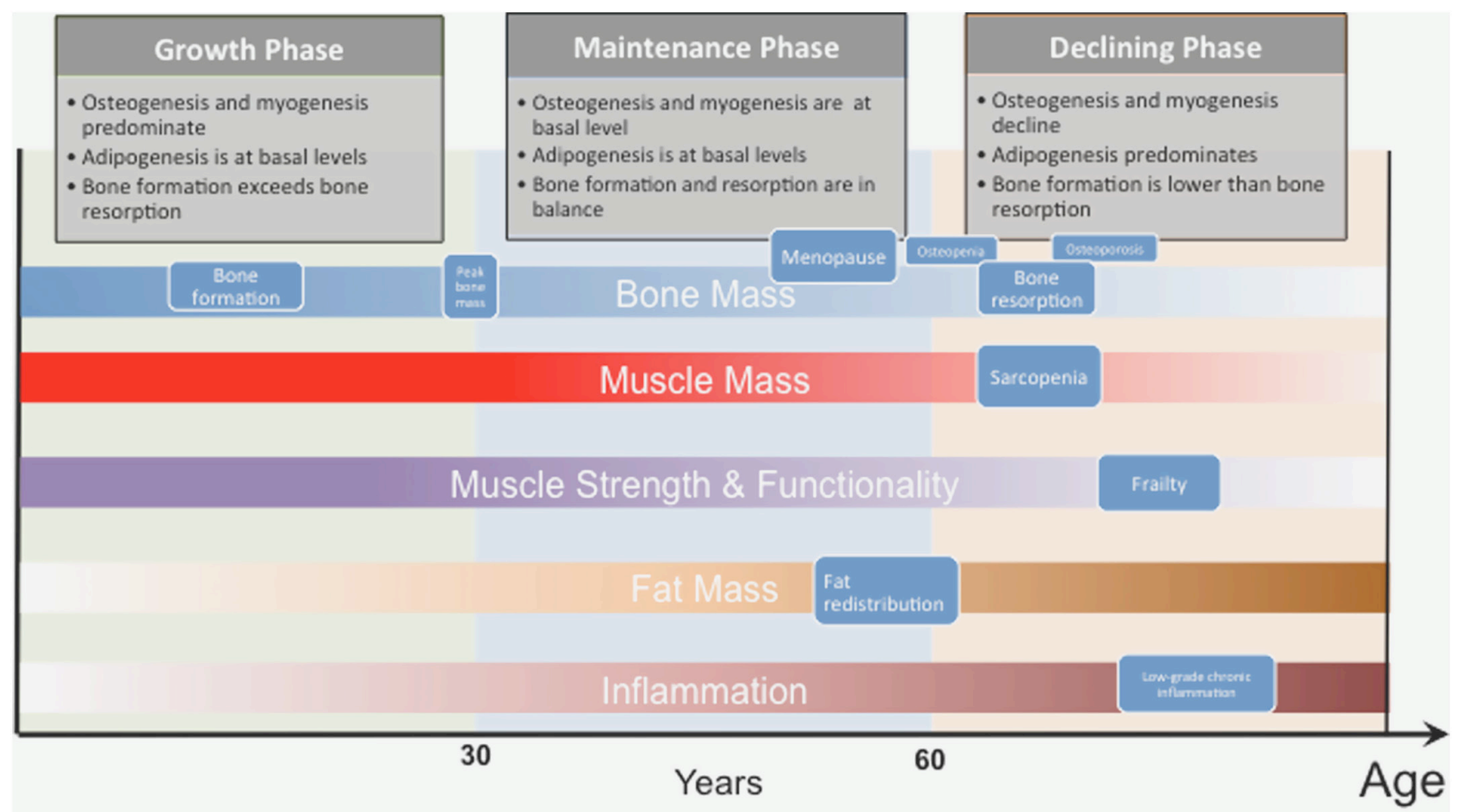

A lighter color intensity indicates a lower value or decrease; a darker color intensity indicates a higher value or increase

\section{Figure 1}

Changes in bone, muscle and fat tissues with increasing age (indicating some typical events), and accompanying increase in low-grade chronic inflammation.

For example, the typical Western-type diet is characterized by over-consumption of $n-6$ polyunsaturated fatty acids (PUFA) coupled with under-consumption of $n-3$ PUFA resulting in LGCI and, along with the subsequent increased presence of reactive oxygen species, leads to a shift in mesenchymal stem cells (MSC, precursors for both osteoblasts and adipocytes) lineage commitment toward increased adipogenesis and suppressed osteoblastogenesis. In turn, increased adipogenesis propagates obesity and synthesis of pro-inflammatory cytokines which promote osteoporosis and maintain LGCI in a 'vicious cycle' (Ilich et al. 2014a).

As aging uniquely influences many physiological functions, the most observable are those regarding body composition changes, including loss of bone, loss of muscle mass and strength, and increased body fat leading to osteosarcopenic obesity syndrome (Ilich et al. 2014b, 2016, JafariNasabian et al. 2017). These changes in body phenotype will be discussed in this review, addressing also the hormonal influences and cellular mechanisms leading to tissue and whole-organism changes. We will also address the changes in nutrient requirements, as well as the dietary intake of elderly, focusing on the Westerntype diet, often causing or propagating some ill outcomes.

\section{Changes in body composition with aging}

There is a 5-25\% decrease in basal (resting) metabolic rate, leading, most notably, to gain in body weight and body fat, even with the unchanged dietary (energy) intake and exercise habits (St-Onge \& Gallagher 2010). For example, for most individuals, body fat starts gradually increasing between 20-25 years of age, until about 65 years (Wilson \& Kannel 2002, Hunter et al. 2010). Even more important is the redistribution of fat to the abdominal area and visceral organs, as well as its infiltration into muscle and bone. The infiltration of fat into bone marrow is not necessarily related only to aging, but occurs early in life, as well as in anorexia and during starvation (Hunter et al. 2010, Lang et al. 2010, Bredella et al. 2014, Ilich et al. 2014b). On the contrary, both muscle and bone tissues decrease with age. Muscle mass peaks at the age of approximately 30 years and then gradually declines. There is about $20-40 \%$ decrease in muscle mass by the age of 70 years, leading to sarcopenia (Cohn et al. 1980, Kalyani et al. 2014). However, it is important to distinguish between sarcopenia and dynapenia, the latter being the loss of muscle strength and not necessarily always proportionally accompanied by muscle mass loss (Clark \& Manini 2008). 
These declines are more pronounced in women than in men (Cruz-Jentof et al. 2010). Changes in bone and the development of osteopenia/osteoporosis with aging are probably most studied. Bone mineral density (BMD), used as a proxy for the assessment of fracture risk, declines with age starting at about 50 years of age. However, equally important is the increase in the bone turnover rate with age, driven by the increased bone resorption, leading to bone loss (Riggs et al. 1996). Women may lose up to $20 \%$ of bone mass during the 5-7 years following menopause. Afterward, the loss continues at the rate of $0.5-1 \%$ per year (unless there is some adverse underlying condition or immobilization; when the rate is higher) (National Osteoporosis Foundation, available at: https:// www.nof.org/prevention/general-facts/what-womenneed-to-know/). Men lose bone mass with age too, but the loss starts later in life and persists at about $0.5-1 \%$ / year (National Osteoporosis Foundation, available at: https://www.nof.org/prevention/general-facts/just-formen/). Figure 1 depicts the hypothetical changes in body composition with accompanying increase in LGCI with age. Approximate ages and onset of some typical events are presented as well.

Recently, a triad encompassing the simultaneous deterioration in bone, muscle and adipose tissues has been identified and named osteosarcopenic obesity syndrome (Ilich et al. 2014b, 2016, JafariNasabian et al. 2017). Although the original identification of osteosarcopenic obesity syndrome was based on the changes in body composition phenotype in older women, it has recently been shown that such phenotype might exist even in young (18-21 years) overweight adults (Stefanaki et al. 2016). Within the osteosarcopenic obesity syndrome, there are two other underlining components that have not been fully recognized until recently: osteopenic/osteoporotic obesity and sarcopenic obesity, of which each one could also exist on its own (Ilich et al. 2014b, 2016). All of these conditions may lead to increased risk of fractures and morbidity and declined functionality (Fig. 2).

It is apparent that all three tissues are closely interrelated and that osteopenia/osteoporosis, sarcopenia and increased adiposity with aging need to be evaluated concomitantly. While some attempts are made in that direction, fat tissue is still kept out of the picture in most cases, and not evaluated in the scope of its interaction with the former two, possibly because of the difficulties in measuring the infiltrated fat into bone and muscle, as well as of the lack of consensus regarding the obesity classification. Obesity classifications in the clinical setting are often based on body mass index (BMI), and its inadequacy for the classification of individuals into normal weight, overweight and/or obese category has been addressed previously (Coutinho et al. 2011). Therefore, more appropriate assessment of overweight/ obesity, especially in older individuals, is to assess the percent body fat using dual-energy X-ray absorptiometry

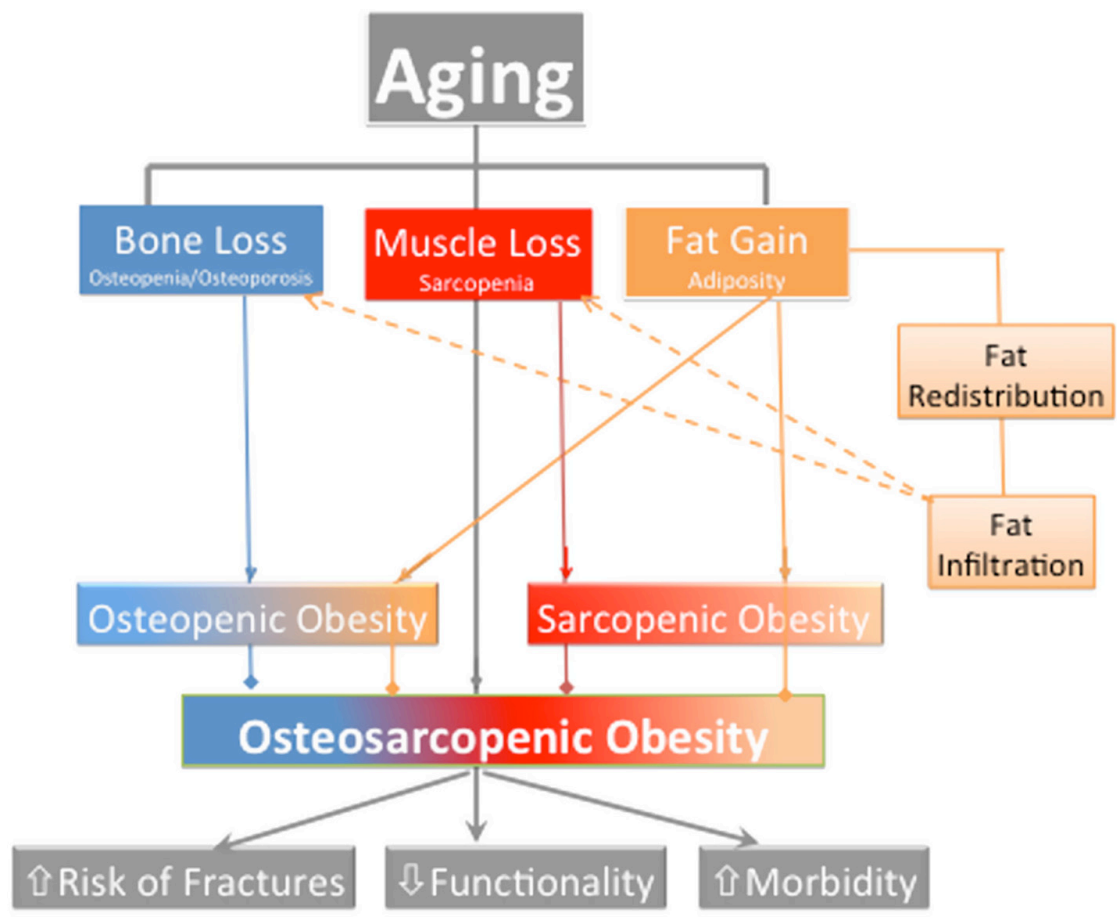

Figure 2

A path of bone, muscle and fat tissues deterioration leading to osteosarcopenic obesity and its consequences.

๑) 2017 Society for Endocrinology Printed in Great Britain 
or bioelectrical impedance analysis (Shea et al. 2012). However, there is still no consensus as to what level of body fat defines obesity in women or men. Recently, some researchers and fitness professionals used body fat of $32 \%$ as the cutoff for overweight/obesity in women (Ilich et al. 2016, Wanner et al. 2016). In other studies, the $35 \%$ body fat as a cutoff was used for obesity classification (Ilich et al. 2015) and that of 33\% and/or 38\% showed adverse influence on various skeletal sites (Liu et al. 2014). With an increased awareness of body fat causing derangements at many levels, we recommend a lower cutoff for obesity for women, specifically, 32-35\% of body fat, than currently proposed by WHO (40\%).

\section{Changes in dietary intake and nutrient requirements with aging}

It is well established that some elderly individuals consume less food due to various reasons among which the diminished appetite secondary to some chronic diseases and/or poor dentition, changes in taste/smell, swallowing issues and food insecurity may be predominant (Pray et al. 2010). Additionally, absorption of many nutrients decreases with age, creating an environment conducive to multiple nutritional deficiencies (Pray et al. 2010). Another major issue interfering with nutrient absorption and/or intake in elderly is the use of multiple medications, known as polypharmacy. For example, research on proton pump inhibitors (PPI) and $\mathrm{H}_{2}$ blockers, the medications that were used in 2013 by over 15 million Americans (Lazarus et al. 2016), has shown their interaction with the absorption of vitamin $\mathrm{B}_{12}$, vitamin $\mathrm{C}$, calcium, magnesium and iron (Heidelbaugh 2013). Similarly, based on the recent review, the long-term use of metformin, a drug widely used by millions for pre-diabetes and diabetes treatment, has also been shown to increase the risk of vitamin $B_{12}$ deficiency (Reilly \& Ilich 2016). It is very likely that an elderly person might be taking both PPI and metformin, yet there is no protocol for regular testing of vitamin $B_{12}$ status in these patients. A clear clinical definition of polypharmacy has yet to be established and may include the use of multiple, duplicate, excessive and/or unnecessary medications (Farrell et al. 2013, Maher et al. 2014). Complications associated with polypharmacy among the elderly include increased falls, functional decline, trouble in performing daily tasks and increased risk of malnutrition (Maher et al. 2014). While the benefit of most prescription drugs outweighs the nutritional risk, there is a lack of research reporting on the cumulative nutritional impact of multiple drugs in the elderly.

Macronutrients and the aging body Nutritional requirements also change during the aging process. As metabolism slows, energy needs decrease but since absorption becomes less efficient, there is a higher need for nutrient-dense foods, typically referred to those which contain more nutrients (minerals, vitamins, protein, complex carbohydrates) but less energy (kcal) per unit of weight (https://nihseniorhealth.gov/ eatingwellasyougetolder/choosenutrientdensefoods/01. html; Pray et al. 2010). Western-type diets, typically referred to as diets high in red meat, saturated fats, simple sugars, sodium and processed food and low in fruits, vegetables and whole grains (Ilich et al. 2014a), are falling short of these needs, and there is still controversy regarding optimal intake of several nutrients, including protein. Although the current recommended dietary allowance (RDA) for protein is $0.8 \mathrm{~g} / \mathrm{kg}$ body weight/day for adults over the age of 19 years (Institute of Medicine, http://www.nationalacademies.org/hmd/Reports/2002/ Dietary-Reference-Intakes-for-Energy-CarbohydrateFiber-Fat-Fatty-Acids-Cholesterol-Protein-and-AminoAcids.aspx), several nitrogen balance studies conducted in individuals ranging in age from 56 to 80 years have suggested that higher amounts of protein intake (1.4-1.6 $\mathrm{g} / \mathrm{kg} /$ day) would be better for older adults (Campbell et al. 1994, Churchward-Venne et al. 2014). About 10-25\% of older adults consume less than $0.8 \mathrm{~g} / \mathrm{kg} /$ day of protein (RDA), and $5-9 \%$ of older adults consume less than the estimated average requirement of protein (the average intake estimated to meet the requirements of half of the healthy individuals in a group - it is usually $20 \%$ lower than RDA) (Fulgoni 2008; http://www.nationalacademies. org/hmd/ /media/Files/Activity\%20Files/Nutrition/DRITables/1_\%20EARs.pdf?la=en). Individuals with higher protein intake lose less lean mass with aging (Hannan et al. 2000, Houston et al. 2008) and have improved muscle protein synthesis. Physical inactivity (common in elderly) combined with inadequate protein intake may further aggravate muscle loss. With inadequate protein intake, bone health might be affected as well; lower BMD was associated with below median intakes of protein in postmenopausal women (Ilich et al. 2003, Bonjour 2011).

Other macronutrients intake may change in elderly, along with their requirements. A recent analysis of National Health and Nutrition Examination Survey (NHANES) data 
revealed that energy imbalance, lower protein intakes, high level of simple carbohydrates and low omega-3 (n-3) PUFA may contribute to osteosarcopenic obesity syndrome (Kelly et al. 2017). This analysis confirmed the paradox regarding energy intake: the latter is reduced with aging in both men and women and across all survey years, yet there is a gain in weight with aging. Reduced energy ultimately results in reduced protein consumption in elderly (Rousset et al. 2003). Regarding the carbohydrate intake, simple sugars account for up to $54 \%$ of kcal from carbohydrates or up to $30 \%$ of total kcal (versus less than $10 \%$ of recommendations), across all ages and all survey years, contributing to the unhealthy diet (Ilich et al. 2014a, Kelly et al. 2017). Omega-3 PUFA, particularly rich in fish, are generally recognized as having protective anti-inflammatory properties that contribute to the prevention of pathological conditions associated with aging (Ubeda et al. 2012). Results from the Framingham Osteoporosis Study showed that consuming $>3$ servings of dark fish (500-1500 mg n-3/serving) per week was associated with maintenance of femoral neck BMD (Farina et al. 2011). Some research indicates that a diet low in n-3 PUFA and high in n-6 PUFA promotes LGCI leading to dysregulation of mesenchymal stem-cell lineage and resulting in obesity and osteoporosis (Kelly et al. 2013). Regrettably, the Western-type diet provides more than 10 times higher levels of $n-6$ compared to n-3 PUFA, enabling an environment conducive to LGCI, obesity and other adverse chronic conditions. Therefore, the recommendations are geared toward lowering the $\mathrm{n}-6 / \mathrm{n}-3$ ratio by reducing $\mathrm{n}-6$ and increasing $\mathrm{n}-3$ PUFA consumption, although it might be difficult to maintain the precise ratio between the two (Office of Dietary Supplements website, available at: http://ods.od.nih.gov/ factsheets/Omega3FattyAcidsandHealth-HealthProfessi onal/\#disc; Kelly et al. 2013, Kim et al. 2013, Ilich et al. 2014a).

Micronutrients and the aging body Micronutrients play a critical role in healthy aging as well. The recent analysis of NHANES data regarding micronutrients intake indicates that several deficiencies and/or excesses throughout decades, typical for Western-type diet, might play a role in the development of many chronic diseases, including osteosarcopenic obesity (Kelly et al. 2016). Regarding minerals, the analysis shows that older women consume diets habitually deficient or insufficient in calcium, magnesium and potassium but consume excess of sodium, phosphorus and iron. Regarding vitamins, there is a lower consumption of fat-soluble vitamins D, E and $\mathrm{K}$ (despite adequate fat intake), as well as vitamins $\mathrm{C}$ and $\mathrm{B}_{6}$, which all in combination or on individual level might be impacting the metabolism of other nutrients, and possibly increasing the morbidity (Kelly et al. 2016). Therefore, it might be reasonable to start evaluating the ratios of minerals and vitamins consumed with diet and/or supplement, as opposed to focusing on absolute amounts.

It needs to be noted that most of the dietary evaluations described above are based on the reports from NHANES surveys. Although all surveys of dietary intake have their flaws and shortcomings (Archer et al. 2013) due to underreporting, poor recalls as well as inaccurate data-bases for nutrient contents in food, the NHANES surveys present the largest collection of dietary intake of nutrients, based on tens of thousands of people, across different ages, genders and over multiple years. Thus, it is reasonable to assume that trends and estimates from NHANES data are close to real values and could be used in evaluating intake of American people.

Regarding the nutrients affecting bone health, calcium and vitamin $\mathrm{D}$ have been investigated most intensely, but other nutrients have been recognized as well, as reported earlier (Ilich \& Kerstetter 2000). Many studies have shown that increased calcium intake was beneficial for BMD although effects of dietary calcium on BMD, particularly on bone fractures, are still a source of controversy. Several studies supported the role of calcium supplements in reducing the risk of fracture in postmenopausal women (Chapuy et al. 1992, Chevalley et al. 1994, Recker et al. 1996), but there have been notable exceptions or inconclusive findings, some generated from the Women Health Initiative findings (Reid \& Bolland 2014). Due to the calcium threshold effect on bones, as elegantly articulated by late Robert Heaney ('.....calcium functions as a threshold nutrient, that is, calcium retention improves as calcium intake rises, up to some threshold intake value, above which no further increase in intake will alter retention') (Heaney 2007), supplementation above the recommended level may not be advantageous, or needed. Another nutrient that received attention regarding bone health has been sodium because of the positive relationship between urinary sodium and urinary calcium. Many studies showed higher urinary calcium excretion with higher urinary sodium (Matkovic et al. 1995, Dawson-Hughes et al. 1996). This relationship was a base for speculation that excess sodium would lead to higher urinary calcium excretion and subsequent decrease 
in BMD and possible detrimental effect on bone health. However, a more recent study showed that higher sodium intake (average $\sim 3,000 \mathrm{mg} /$ day) did not have negative effects on bone as long as adequate calcium and vitamin D was consumed (Ilich et al. 2010). On the contrary, it has been shown that salt restricted diets increase the risk of involuntary weight loss among long-term care facilities residents. Therefore, liberalizing the diet to allow salt, was beneficial for preventing unintended weight loss (Niedert 2005).

The studies examining the deficiency or excess of other minerals and vitamins and their impact on various aspects of body composition or functionality in aging are numerous, and such review is out of scope of this paper. More information can be found at the National Institute on Aging website, available at: https://www.nia.nih.gov/ health/publication/healthy-aging-lessons-baltimorelongitudinal-study-aging/introduction).

\section{Interaction among aging tissues}

Previously, it was believed that obesity has a protective role on bone and muscle, by providing mechanical load for both and stimulating their accrual, as well as by being a source of extra-glandular estrogens (Bélanger et al.2002). It is well established that estrogen is beneficial for reducing bone resorption (Kameda et al. 1997), signaling muscle repair and regeneration, and reducing adipogenesis (Reid 2008). However, in the recent years, the concerns regarding bone/muscle health and obesity are getting more attention in the scientific community. It is now recognized that adipose tissue is an endocrine organ, releasing hormones (beyond estrogen) and other cytokines (Dodds et al. 1994, Wellen \& Hotamisligil 2005, Cao 2011, Mantzoros et al. 2011, Ilich et al. 2014b). Particularly the visceral fat is considered a unique pathogenic fat depot that has a negative impact on bone and muscle (Gilsanz et al. 2009, Zhang et al. 2015). Visceral fat secretes pro-inflammatory cytokines such as tumor necrosis factor-alpha (TNF- $\alpha$ ), interleukin 1 and 6 (IL-1 and IL-6) and C-reactive protein (in high inflammatory states), all known as strong proinflammatory cytokines, promoting and sustaining LGCI beyond the aging processes (Pradhan et al. 2001, Liu et al. 2012, Ilich et al. 2014a). It is increasingly recognized that mechanisms of LGCI cause derangement of all three tissues simultaneously and propagate more fat deposition, maintaining disordered conditions (Ilich et al. 2014a, 2014b, Zhang et al. 2015).

It is now clear that there is a very fine inflection point indicating the changing effect of body fat on bone.
As shown in a recent study conducted in almost 500 healthy women, body fat higher than 33\% was negatively related to femoral neck BMD and that of $38 \%$ to lumbar spine and total-body BMD (Liu et al. 2014). This is lower than the current cutoff for obesity being set at $40 \%$ body fat for women (Dufour et al. 2013). As discussed above, different researchers used different levels for obesity classification in women, depending on the studied population and parameters examined (Ilich et al. 2015, 2016, Wanner et al. 2016). Moreover, Bosch and coworkers identified a cutoff of $38.3 \%$ body fat in women as an inflection point where the slope of the relation between visceral fat and percent body fat increases significantly (Bosch et al. 2015). In other words, weight gain in older adults leads to greater visceral fat accumulation and possibly long-term bone and muscle impairments as a consequence. This all disputes the notion that obesity is protective for bone health as once thought, especially in aging women (Ilich et al. 2014a, 2014b, Shin et al. 2014). However, the relationship between obesity and bone is of a complex nature as addressed in recent reviews (Shapses et al. 2012, Iwaniec et al. 2016), and more research is needed to determine the threshold at which body fat becomes harmful for bones and/or muscle (Liu et al. 2014).

Bone marrow adipose tissue (MAT) increases with aging, obesity and in osteoporosis, thereby also interconnecting bone and fat tissues. Some suggest that MAT should be considered a biomarker for osteoporosis risk in older adults (Scheller \& Rosen 2014). MAT appears to reduce osteoblast and osteoclast activity, slowing bone turnover (although the decreased bone turnover might be beneficial in situations like menopause), as well as decreasing the rate of bone accrual (Scheller \& Rosen 2014). Recent studies show a negative correlation between MAT and BMD (Liu et al. 2010, Tang et al. 2010, Bredella et al. 2014). Still, there is a lack of evidence as to whether the relationship with MAT and osteoporosis is causative or just correlative (Scheller \& Rosen 2014), possibly because MAT predominates in long bones that are not particularly prone to low-trauma fractures.

Regarding adiposity and muscle connection, a prospective study by Kim et al. (2014) showed that postmenopausal women with higher amount of visceral fat lost significantly more lean mass over a 27-month period than women with lower amount of visceral fat (Kim et al. 2014). However, this study was performed in Korean women and might not be applicable for other ethnicities. This decrease in muscle mass did not result in a parallel change in BMI, as fat appeared to replace the lost muscle tissue, possibly infiltrating it (Zhang et al. 2015).

Published by Bioscientifica Ltd. 
Multiple studies support a causal role of pro-inflammatory cytokines such as TNF- $\alpha$ and IL-6 in muscle wasting and their elevated serum concentration in sarcopenia and sarcopenic obesity (Schaap et al. 2009, Mavros et al. 2014). Additionally, muscle mass is the main determinant of resting metabolic rate (energy expenditure) and loss of muscle would in turn also promote weight gain and fat accumulation. Hence, muscle and bone loss and visceral fat accumulation with aging aggravated by overall excess of adiposity, appear to be part of a cycle where increased inflammation from visceral fat favors sarcopenia and osteopenia, promotes obesity and ultimately, in turn, a greater visceral fat accumulation (Ilich et al. 2014a, Bosch et al. 2015).

Another consequence of aging recently recognized in older adults (and briefly mentioned above), is myosteatosis, or fat infiltration into muscle. As skeletal muscle ages, muscle fat in the form of intra- and extra-myocellular adipocytes (droplets of triglyceride) is embedded within and between muscle fibers resulting in increased storage of lipid droplets (Lang et al. 2010). Myosteatosis is seen in older women, even if they do not appear clinically obese or overweight, but it could also be seen in obese younger individuals, as shown recently (Stefanaki et al. 2016). In the same manner, we propose here a new term, osteosteatosis, indicating increased adipogenesis in bone marrow. Although the term osteosteatosis has not been officially proposed until now, there is plenty of evidence showing that the MSC in bone marrow (precursors of both adipocytes and osteoblasts) may favor adipogenic differentiation in the presence of excessive adiposity (Pittenger et al. 1999, Rosen \& Bouxsein 2006, Ilich et al. 2014b, Kim et al. 2014). It is for this reason that osteoporosis might be characterized as 'the obesity of bone' (Rosen \& Bouxsein 2006) and sarcopenia as 'obesity of muscle' (Ilich et al. 2014b). Although fat infiltration is also a normal aging process, its elevation in an obesogenic environment exacerbates other processes, like loss of bone or muscle. Therefore, osteosteatosis and myosteatosis, combined with age-related loss of bone and muscle mass, contribute even more to loss of bone and muscle strength and overall function (Visser et al. 2003, Lang et al. 2010, Domiciano et al. 2013, Ilich et al. 2015).

Loss of functionality and inadequate mobility set an older adult at increased risk for falls and bone fractures. Furthermore, as shown recently, myosteatosis may lead to the development of disorders such as diabetes that also increases the risk of falls secondary to impaired vision and/or neuropathy (Lang et al. 2010) and contributes to increased risk for fractures (Lang et al. 2010, Hamrick et al. 2016). This may help explain the increased risk of frailty in older adults, not just in those who suffer from osteosarcopenic obesity, but also in those with each of the underlying conditions, osteopenic obesity and/ or sarcopenic obesity (Domiciano et al. 2013, Ilich et al. 2015), as indicated in Fig. 2. We showed recently that older women suffering from osteopenic obesity, sarcopenic obesity and/or osteosarcopenic obesity (as an ultimate fate of former two) were inferior in several of the functional performance measures, compared to their obese-only counterparts. Even more so, those suffering from osteosarcopenic obesity showed significantly poorer performance in handgrip strength, balance and walking speed, compared to each other group (Ilich et al. 2015).

Increasingly, recent research is focusing on the interaction among bone, muscle and fat tissues and connecting some major functional impairments or nutritional deficiencies with osteosarcopenic obesity syndrome (Ilich et al. 2015, Kim et al. 2016). Chung and coworkers found that older adults with sarcopenic obesity had greater risk of osteoporosis, as the physical decline from the former appeared to promote greater loss of bone (Chung et al. 2016). Overall, the physical decline resulting from any of the conditions, e.g. osteopenic obesity or sarcopenic obesity, could potentially aggravate other conditions, feeding a perpetual loop and ultimately leading to osteosarcopenic obesity. Someone with impaired mobility from sarcopenic obesity, for example, may go on to suffer greater bone loss and fractures (Ilich et al. 2015, Chung et al. 2016). Taken together, overall body composition, corresponding serum biomarkers (indicating impairments in bone, muscle and fat tissues), nutrition and physical performance should all be taken into consideration when evaluating the health of older adults (Ilich et al. 2014b, 2015).

\section{Hormonal changes in aging body and their influence on body composition}

Besides estrogen (as briefly mentioned above), a number of other key hormones/cytokines are altered with aging, and by that affect body composition and might contribute to the osteosarcopenic obesity syndrome. It is now recognized that bone, muscle and fat are interconnected and act as endocrine organs (Mantzoros et al. 2011, Karsenty \& Ferron 2012, Pedersen \& Febbraio 2012, Ilich et al. $2014 b$ ), each secreting hormones and molecules that have autocrine, paracrine and endocrine effects - influencing
Published by Bioscientifica Ltd 
each other, acting on other tissues and changing with age. Therefore, the next section briefly discusses the three tissues as endocrine organs.

Calcitriol as a mediator for all three tissues Vitamin D, as hormone calcitriol (1, 25-dihydroxyvitamin D), influences bone, muscle and adipose tissue throughout the life cycle, with probably the most important role during growth and in older age. Its status might be compromised in elderly due to several reasons including: lower vitamin D intake, decreased skin production of cholecalciferol (the first precursor of active vitamin D) partly due to lower sun exposure, decreased activity of both liver and renal hydroxylases leading to lower conversion to calcidiol (25-hydroxyvitamin D) and calcitriol in liver and kidney, respectively (Gallagher 2013). The disturbance in vitamin D leads to decreased calcium absorption, partly related to abnormalities in the calcium transport proteins that are regulated by calcitriol. In summary, both calcium and vitamin D absorption are diminished with aging leading to their lower serum concentration (Gallagher 2013). There is a strong relationship between low calcidiol concentrations and increasing levels of obesity (Pereira-Santos et al. 2015). It has been shown that even when controlling for sunlight exposure, obese individuals are significantly more likely to have lower calcidiol concentration, indicating inadequate vitamin D status (Cheng et al. 2010, Pereira-Santos et al. 2015). Moreover, inadequate vitamin D can increase adipogenesis by promoting higher parathyroid hormone (PTH) secretion and greater influx of calcium into adipocytes (Wood 2008). Similarly, low serum calcium could promote increase of circulating calcitriol and PTH, which then stimulate influx of extracellular calcium into adipocytes via a specific-membrane vitamin D receptor, again promoting adipogenesis (Zemel et al. 2005).

Regarding bone health, calcitriol is essential for normal bone turnover and maintenance, as well as for metabolism of the minerals calcium, phosphorous and magnesium (Pereira-Santos et al. 2015). A decrease in calcitriol could disturb calcium homeostasis and impair bone health. Numerous studies have addressed the role of vitamin D in bone health and fracture incidence (Holick et al. 2005, Garnero et al. 2007), and further discussion is out of scope of this review. However, both recommendations of vitamin $\mathrm{D}$ intake and adequate serum concentrations of calcidiol still remain controversial. The latter is even more hindered in view of unreliable and often inaccurate analytical methods for its detection (Snellman et al. 2010).
Although the official RDA for vitamin D for older individuals was increased in recent years to 600-800 IU/ day (15-20 $\mu \mathrm{g} /$ day) (Institute of Medicine 2012), some argue that it is still not enough to keep adequate serum concentration of calcidiol (Heaney \& Holick 2011). With that regard, there are still disagreements about serum concentration of calcidiol reflecting adequacy, inadequacy or true deficiency (Holick et al. 2005, Institute of Medicine 2012).

Regarding the muscle, inadequate vitamin $\mathrm{D}$ has recently been associated with sarcopenia, decreased grip strength and other impaired functionality measures in older adults (Visser et al. 2003, Lee et al. 2013, Post \& Ilich 2013, Tieland et al. 2013). Recent studies also showed that inverse relationship between vitamin D status and PTH concentrations is associated with compromised muscle mass and strength, as well as with diminished physical function (Lee et al. 2013, Tieland et al. 2013). A study in the Netherlands investigating older women and men showed that low calcidiol and high PTH increase the risk of sarcopenia, as reflected in lower muscle mass and hand grip strength (Visser et al. 2003). Tying this to bone, another study has found that patients with insufficient calcidiol concentrations and low BMD are also more likely to develop sarcopenia (Lee et al. 2013).

Bone as endocrine organ Considering bone as an endocrine organ, most research has probably been done on osteocalcin, an osteoblast-secreted protein, also referred to as bone $\gamma$-carboxyglutamic acid (Gla) protein. Once synthesized, it is largely incorporated into the extracellular bone matrix (hydroxyapatite), but a low concentration is maintained in serum and is used as an indicator of bone formation (Hauschka et al. 1989, Lee et al. 2000). Typically, the majority of osteocalcin is carboxylated with vitamin-K-dependent $\gamma$-glutamyl carboxylase and as such binds easily to $\mathrm{Ca}^{2+}$ ions within the hydroxyapatite matrix and stabilizes the bone (Lee et al. 2000). However, in cases of low carboxylase activity (e.g. as with inadequate vitamin $\mathrm{K}$ status, often present in elderly), there will be an increased presence of undercarboxylated osteocalcin which does not readily bind to hydroxyapatite, thus possibly contributing to bone loss (Price \& Nishimoto 1980). Other than stabilizing the bone matrix, osteocalcin stimulates secretion of adiponectin from fat cells, demonstrating the connection between bone and adipose tissue (Lee \& Karsenty 2008).

It was hypothesized recently that small but measurable amounts of undercarboxylated osteocalcin are present in

Published by Bioscientifica Ltd 
serum (either due to osteocalcin decarboxylation outside the osteoblasts or its secretion in undercarboxyated form) (Karsenty \& Ferron 2012). This undercarboxylated osteocalcin was shown to stimulate pancreatic $\beta$-cell proliferation and insulin secretion via embryonic stemcell phosphatase expressed in osteoblast and thus positively modulate energy metabolism (Kanazawa et al. 2009, Karsenty \& Ferron 2012).

Overall, new research points into systemic hormonal actions of osteocalcin and/or undercarboxylated osteocalcin, on which basis this hormone was recently termed as the first osteokine (Ilich et al. 2014b), analogous to the myokines and adipokines, the hormones secreted from muscle and adipose tissues, respectively.

Muscle as endocrine organ Muscle tissue has just begun to be investigated as an endocrine organ. Troponins, the key regulatory proteins associated with the contractility process of cardiac and skeletal muscle, are receiving the most attention. Troponins are not normally found in the blood, except in cases of muscle turnover or muscle damage. Skeletal muscle contraction is regulated by $\mathrm{Ca}^{2+}$ via the skeletal muscle specific troponin (sTnT). This complex is needed for the repetitive cycles of contraction and relaxation. Skeletal muscles are protected by several layers of connective tissue, which maintain the muscle integrity. If this barrier is injured, internal components of muscle, particularly sTnT, leak into the blood and their measurable presence could indicate sarcopenia (Chase et al. 2013, Kalinkovich \& Livshits 2015). Serum sTnT drops proportionally with improvements in handgrip strength and overall physical fitness in older adults, as recently reviewed (Abreu et al. 2014).

Fat as endocrine organ Regarding the fat tissue, the classic hormone secreted by adipocytes is leptin (Reid 2008). This member of the cytokine family has structural similarities to IL- 6 and stimulates the pro-inflammatory action of IL-6, interlukin-12 (IL-12) and TNF- $\alpha$ (Abenavoli \& Peta 2014, Pires et al. 2014). Leptin is higher in women and proportionally increases with increasing fat tissue (Pires et al. 2014), but it gradually decreases with age; this reduction is higher in females than in males and is independent from BMI (Isidori et al. 2000).

Leptin locally enhances osteoblastogenesis and inhibits osteoclastogenesis (Gordeladze et al. 2002, Karsenty \& Ferron 2012). As some recent studies showed, the osteoblastogenic effect is due to leptin's mediation of bone marrow MSC that may differentiate into osteoblasts, chondrocytes and/or adipocytes. For example, transfection of leptin into MSC of osteoporotic rats, increased osteoblast differentiation and mineral deposition both in vivo and in vitro (Zheng et al. 2015), while hypothalamic leptin gene therapy reduced MAT in $o b / o b$ mice, fed either high-fat or regular diet (Lindenmaier et al. 2016). Positive effects of leptin on bone and accelerated fracture healing were shown in rats with induced femoral fractures after peritoneal exogenous leptin injection. This effect was attributed to increased angiogenesis, osteogenesis and chondrogenesis (Liu \& Cai 2017). Moreover, a recent study showed that different lower dose-infusions of leptin (4-12-40 $\mathrm{ng} / \mathrm{h}$ ) in $o b / o b$ mice resulted in increased bone formation and trabecular thickness, with a minimal impact on energy metabolism (Philbrick et al. 2017).

However, the central effect of leptin could be characterized in either positive or negative regulation of bone metabolism (Karsenty 2001, Gordeladze et al. 2002). Thus, the conflicting results of the relationship of leptin and BMD were reported in several studies (Iwamoto et al. 2000, Dennison et al. 2004, Weiss et al. 2006, Koroglu et al. 2011). Leptin passes through the blood brain barrier and activates the leptin receptor in the hypothalamus. Activated receptor suppresses serotonin secretion in the brainstem, and in the absence of serotonin, the sensory nervous system sends signals to osteoblasts by secretion of norepinephrine. The binding between norepinephrine and $\beta_{2}$-adrenergic receptors on osteoblasts increases receptor activator of nuclear factor kappa-b ligand (RANKL) gene expression, decreases bone formation and increases bone resorption (Motyl \& Rosen 2012). Similarly, a previous evidence from a study conducted on $\beta_{2}$-adrenergic receptors deficient mice showed reduced RANKL expressions (Elefteriou et al. 2005).

Obesity can lead to leptin resistance and hyperleptinemia. Additionally, leptin also appears to activate pro-inflammatory pathways in osteoblasts (Upadhyay et al. 2015), contributing even more toward bone deterioration. Conversely, decreased serum leptin is found in frail elderly and in cachexia (Hubbard et al. 2008). However, the hyperleptinemia in osteosarcopenic obesity may mask this, possibly causing patients with osteosarcopenic obesity to be overlooked in clinical settings (Hubbard et al. 2008, Ilich et al. 2014b).

Adiponectin is another hormone that has been investigated as a possible link between bone and fat tissue. Adiponectin is mainly secreted by adipocytes, but also by osteoblasts, myocytes and it is even expressed in the brain (Lee \& Shao 2012). Circulating adiponectin is decreased in

Published by Bioscientifica Ltd. 
obese states but increased in lean states, as well as during energy restriction, weight loss and in older individuals (Ambroszkiewicz et al. 2015). Recently, Cawthorn et al. (2014) showed that MAT may contribute to increased serum adiponectin, even more than white adipose tissue, during energy restriction and some other conditions (e.g. cancer therapy) (Cawthorn et al. 2014). Low serum adiponectin concentrations or hypoadiponectinemia $(<4 \mu \mathrm{g} / \mathrm{mL})$ are associated with osteoporosis (Kishida et al. 2014); however, adiponectin also has a dual impact on bone (Luo et al. 2006, Williams et al. 2009). Some studies show that adiponectin negatively regulates bone mass by decreasing osteoblast proliferation possibly via mediation of the RANK/RANKL/ osteoprotegerin (OPG) axis (Luo et al. 2006, Lewerin et al. 2015). Other studies show that through the same RANK/RANKL/OPG axis, adiponectin may inhibit osteoclastogenesis and increase osteoblastic activity and mRNA expression (Oshima et al. 2005, Williams et al. 2009).

Adiponectin is involved in fat metabolism and may inhibit obesity by increasing fatty acid oxidation in adipose tissue by activation of AMP-activated protein kinase (AMPK) phosphorylation and in muscle by P38 mitogen-activated protein kinase (MAPK) and peroxisome proliferator-activated receptor (PPAR) alpha (Yoon et al. 2006, Lecke et al. 2011, Ghoshal \& Bhattacharyya 2015). Furthermore, adiponectin has anti-inflammatory effects inhibiting the action of TNF- $\alpha$ and IL-8 (Ghoshal \& Bhattacharyya 2015). To further connect adiposity, inflammation and adiponection, hypoadiponectinemia $(<4 \mu \mathrm{g} / \mathrm{mL})$ is positively associated with visceral fat and obesity-related diseases (Kishida et al. 2014). These combined effects of adiponectin appear to favor lean mass and possibly promote decreased body fat accumulation (Fiaschi et al. 2012). Predictably, adiponectin serum concentrations would be lower in osteosarcopenic obesity women, due to increased fat mass and decreased lean mass. However, since adiponectin increases with age, its decline in osteosarcopenic obesity in women might be masked.

\section{Conclusions and implications for further initiatives in this field}

Aging causes numerous physiological changes, among which those affecting the physical phenotype are the most observable. An ultimate consequence of deterioration in body composition is the development of osteosarcopenic obesity. This is a complex condition with concomitant changes in bone, muscle and adipose tissue in aging body or occurring in some other chronic diseases. Increased adiposity results in increased inflammation, influencing muscle and bone health, while inflammation perpetuates adiposity (Ilich et al. 2014a). Damage to or decline of one tissue could signal changes in the other, but all ultimately lead to decreased functionality, increased risk for falls and increased morbidity. Therefore, in evaluating the older adults, clinicians should perhaps first assess functional decline through physical performance tests, then assess biomarkers in serum, followed by the assessment of bone and muscle loss to diagnose osteosarcopenic obesity syndrome and any of its components (Ilich et al. 2016). Many questions still remain unanswered and need more investigation and/or confirmation: Do women with osteosarcopenic obesity present with higher levels of chronic inflammation than women with osteoporosis, sarcopenia or obesity alone? Does chronic inflammation exacerbate bone loss, worsen sarcopenia and subsequently lead to lower functionality? Is osteopenia and/or sarcopenia a sign of fat infiltration into bone and muscle, as proposed earlier (Rosen \& Bouxsein 2006, Ilich et al. 2014b)? Could reduced adiposity improve bone health and muscle mass and strength in older people? Based on the newest findings, women with osteosarcopenic obesity appear to have greater risk for functional decline and higher risk for falls and fractures even beyond the normal risk level of their peers with osteopenia/osteoporosis or sarcopenia (Cruz-Jentoft et al. 2010, Ilich et al. 2015). Research into the changes in body composition with aging should evaluate not only the level of frailty in older adults but the overall interconnecting links among bone loss, muscle loss and increased adiposity, as proposed recently (Ilich et al. 2014b).

\section{Declaration of interest}

The authors declare that there is no conflict of interest that could be perceived as prejudicing the impartiality of this review.

\section{Funding}

Related work in JZI laboratory has been funded by the USDA grant (200405287) and Hazel K. Stiebeling professorship.

Authors' contribution statement

J Z I conceptualized manuscript and wrote the final version. J P, J E I, W R and $\mathrm{O} J \mathrm{~K}$ drafted the manuscript. $\mathrm{OJ} \mathrm{K}$ and $\mathrm{J} \mathrm{ZI}$ designed the figures.

Published by Bioscientifica Ltd. 


\section{References}

Abenavoli L \& Peta V 2014 Role of adipokines and cytokines in nonalcoholic fatty liver disease. Reviews on Recent Clinical Trials 9 134-140. (doi:10.2174/1574887109666141216102458)

Abreu EL, Cheng A-L, Kelly PJ, Chertoff K, Brotto L, Griffith E, Kinder G, Uridge T, Zachow R \& Brotto M 2014 Skeletal muscle troponin as a novel biomarker to enhance assessment of the impact of strength training on fall prevention in the older adults. Nursing Research $\mathbf{6 3}$ 75-82. (doi:10.1097/NNR.0000000000000018)

Ambroszkiewicz J, Chelchowska M, Szamotulska K, RychlowskaPruszyńska M, Rowicka G \& Gajewska J 2015 Body composition parameters and adipokines levels in relation to bone mineral density in patients with malignant bone tumors after treatment. Pediatric Blood \& Cancer 62 988-993. (doi:10.1002/pbc.25377)

Archer E, Hand GA \& Blair SN 2013 Validity of U.S. nutritional surveillance: National Health and Nutrition Examination Survey caloric anergy intake data, 1971-2010. PLoS ONE 9 e76632. (doi:10.1371/journal.pone.0076632)

Bélanger C, Luu-The V, Dupont P \& Tchernof A 2002 Adipose tissue intracrinology: potential importance of local androgen/estrogen metabolism in the regulation of adiposity. Hormone and Metabolic Research 34 737-745. (doi:10.1055/s-2002-38265)

Bonjour J-P 2011 Protein intake and bone health. International Journal for Vitamin and Nutrition Research 81 134-142. (doi:10.1024/0300-9831/ a000063)

Bosch TA, Steinberger J, Sinaiko AR, Moran A, Jacobs DR, Kelly AS \& Dengel DR 2015 Identification of sex-specific thresholds for accumulation of visceral adipose tissue in adults. Obesity 23 375-382. (doi:10.1002/oby.20961)

Bredella MA, Fazeli PK, Daley SM, Miller KK, Rosen CJ, Klibanski A \& Torriani M 2014 Marrow fat composition in anorexia nervosa. Bone 66 199-204. (doi:10.1016/j.bone.2014.06.014)

Campbell WW, Crim MC, Dallal GE, Young VR \& Evans WJ 1994 Increased protein requirements in elderly people: new data and retrospective reassessments. American Journal of Clinical Nutrition $\mathbf{6 0}$ 501-509.

Cao JJ 2011 Effects of obesity on bone metabolism. Journal of Orthopaedic Surgery and Research 6 30. (doi:10.1186/1749-799X-6-30)

Cawthorn WP, Scheller EL, Learman BS, Parlee SD, Simon BR, Mori H, Ning X, Bree AJ, Schell B, Broome DT, et al. 2014 Bone marrow adipose tissue is an endocrine organ that contributes to increased circulating adiponectin during caloric restriction. Cell Metabolism 20 368-375. (doi:10.1016/j.cmet.2014.06.003)

Chapuy MC, Arlot ME, Duboeuf F, Brun J, Crouzet B, Arnaud S, Delmas PD \& Meunier PJ 1992 Vitamin D3 and calcium to prevent hip fractures in the elderly women. New England Journal of Medicine 327 1637-1642. (doi:10.1056/NEJM199212033272305)

Chase PB, Szczypinski MP \& Soto EP 2013 Nuclear tropomyosin and troponin in striated muscle: new roles in a new locale? Journal of Muscle Research and Cell Motility 34 275-284. (doi:10.1007/s10974-013-9356-7)

Cheng S, Massaro JM, Fox CS, Larson MG, Keyes MJ, McCabe EL, Robins SJ, O'Donnell CJ, Hoffmann U, Jacques PF, et al. 2010 Adiposity, cardiometabolic risk, and vitamin D status: The Framingham Heart Study. Diabetes 59 242-248. (doi:10.2337/db09-1011)

Chevalley T, Rizzoli R, Nydegger V, Slosman D, Rapin CH, Michel JP, Vasey H \& Bonjour JP 1994 Effects of calcium supplements on femoral bone mineral density and vertebral fracture rate in vitaminD-replete elderly patients. Osteoporosis International 4 245-252. (doi:10.1007/BF01623348)

Chung JH, Hwang HJ, Shin H-Y \& Han CH 2016 Association between sarcopenic obesity and bone mineral density in middle-aged and elderly Korean. Annals of Nutrition \& Metabolism 68 77-84. (doi:10.1159/000442004)

Churchward-Venne TA, Breen L \& Phillips SM 2014 Alterations in human muscle protein metabolism with aging: Protein and exercise as countermeasures to offset sarcopenia. BioFactors 40 199-205. (doi:10.1002/biof.1138)

Clark BC \& Manini TM 2008 Sarcopenia =/= dynapenia. Journals of Gerontology 63 829-834. (doi:10.1093/gerona/63.8.829)

Cohn SH, Vartsky D, Yasumura S, Sawitsky A, Zanzi I, Vaswani A \& Ellis KJ 1980 Compartmental body composition based on total-body nitrogen, potassium, and calcium. American Journal of Physiology 239 E524-E530.

Coutinho T, Goel K, Corrêa de Sá D, Kragelund C, Kanaya AM, Zeller M, Park J-S, Kober L, Torp-Pedersen C, Cottin Y, et al. 2011 Central obesity and survival in subjects with coronary artery disease: a systematic review of the literature and collaborative analysis with individual subject data. Journal of the American College of Cardiology $\mathbf{5 7}$ 1877-1886. (doi:10.1016/j.jacc.2010.11.058)

Cruz-Jentoft AJ, Baeyens JP, Bauer JM, Boirie Y, Cederholm T, Landi F, Martin FC, Michel J-P, Rolland Y, Schneider SM, et al. 2010 Sarcopenia: European consensus on definition and diagnosis: Report of the European Working Group on Sarcopenia in Older People. Age and Ageing 39 412-423. (doi:10.1093/ageing/afq034)

Dawson-Hughes B, Fowler SE, Dalsky G \& Gallagher C 1996 Sodium excretion influences calcium homeostasis in elderly men and women. Journal of Nutrition 126 2107-2112.

Dennison EM, Syddall HE, Fall CH, Javaid MK, Arden NK, Phillips DI \& Cooper C 2004 Plasma leptin concentration and change in bone density among elderly men and women: the Hertfordshire Cohort Study. Calcified Tissue International 74 401-406. (doi:10.1007/s00223002-0017-x)

Dodds RA, Merry K, Littlewood A \& Gowen M 1994 Expression of mRNA for IL1 beta, IL6 and TGF beta 1 in developing human bone and cartilage. Journal of Histochemistry and Cytochemistry 42 733-744. (doi:10.1177/42.6.8189035)

Domiciano DS, Figueiredo CP, Lopes JB, Caparbo VF, Takayama L, Menezes PR, Bonfa E \& Pereira RMR 2013 Discriminating sarcopenia in community-dwelling older women with high frequency of overweight/obesity. Osteoporosis International 24 595-603. (doi:10.1007/s00198-012-2002-1)

Dufour AB, Hannan MT, Murabito JM, Kiel DP \& McLean RR 2013 Sarcopenia definitions considering body size and fat mass are associated with mobility limitations: The Framingham Study. Journals of Gerontology Series A: Biological Sciences and Medical Sciences 68 168-174. (doi:10.1093/gerona/gls109)

Elefteriou F, Ahn JD, Takeda S, Starbuck M, Yang X, Liu X, Kondo H, Richards WG, Bannon TW, Noda M, et al. 2005 Leptin regulation of bone resorption by the sympathetic nervous system and CART. Nature 434 514-520. (doi:10.1038/nature03398)

Farina EK, Kiel DP, Roubenoff R, Schaefer EJ, Cupples LA, Tucker KL 2011 Protective effects of fish intake and interactive effects of long-chain polyunsaturated fatty acids intakes on hip bone mineral density in older adults: The Framingham Osteoporosis Study. American Journal of Clinical Nutrition 93 1142-1151. (doi: 10.3945/ajcn.110.005926)

Farrell B, Shamji S, Monahan A \& French Merkley V 2013 Reducing polypharmacy in the elderly: cases to help you "rock the boat". Canadian Pharmacists Journal 146 243-244. (doi:10.1177/1715163513499530)

Fernández-Real JM \& Ricart W 2003 Insulin resistance and chronic cardiovascular inflammatory syndrome. Endocrine Reviews $\mathbf{2 4}$ 278-301. (doi:10.1210/er.2002-0010)

Fiaschi T, Giannoni E, Taddei ML \& Chiarugi P 2012 Globular adiponectin activates motility and regenerative traits of muscle satellite cells. PLoS ONE 7 e34782. (doi:10.1371/journal.pone.0034782)

Frangeskou M, Lopez-Valcarcel B, Serra-Majem L 2015 Dehydration in the elderly: a review focused on economic burden. Journal of Nutrition Health and Aging 19 619-627. (doi: 10.1007/s12603-015-0491-2)

Fulgoni VL 2008 Current protein intake in America: analysis of the National Health and Nutrition Examination Survey, 2003-2004. American Journal of Clinical Nutrition 87 1554S-1557S. http://joe.endocrinology-journals.org

DOI: $10.1530 / J O E-16-0603$
๑ 2017 Society for Endocrinology Printed in Great Britain 
Gallagher JC 2013 Vitamin D and aging. Endocrinology Metabolism Clinics of North America 42 319-332. (doi:10.1016/j.ecl.2013.02.004)

Garnero P, Munoz F, Sornay-Rendu E \& Delmas PD 2007 Associations of vitamin D status with bone mineral density, bone turnover, bone loss and fracture risk in healthy postmenopausal women. The OFELY study. Bone 40 716-722. (doi:10.1016/j.bone.2006.09.026)

Ghoshal K \& Bhattacharyya M 2015 Adiponectin: probe of the molecular paradigm associating diabetes and obesity. World Journal of Diabetes $\mathbf{6}$ 151. (doi:10.4239/wjd.v6.i1.151)

Gilsanz V, Chalfant J, Mo AO, Lee DC, Dorey FJ \& Mittelman SD 2009 Reciprocal relations of subcutaneous and visceral fat to bone structure and strength. Journal of Clinical Endocrinology \& Metabolism 94 3387-3393. (doi:10.1210/jc.2008-2422)

Glassock RJ \& Winearls C 2009 Ageing and the glomerular filtration rate: truths and consequences. Transactions of the American Clinical and Climatological Association 120 419-428.

Gordeladze JO, Drevon CA, Syversen U \& Reseland JE 2002 Leptin stimulates human osteoblastic cell proliferation, de novo collagen synthesis, and mineralization: Impact on differentiation markers, apoptosis, and osteoclastic signaling. Journal of Cellular Biochemistry 85 825-836. (doi:10.1002/jcb.10156)

Hamrick MW, McGee-Lawrence ME \& Frechette DM 2016 Fatty infiltration of skeletal muscle: mechanisms and comparisons with bone marrow adiposity. Frontiers in Endocrinology 7 69. (doi:10.3389/ fendo.2016.00069)

Hannan MT, Tucker KL, Dawson-Hughes B, Cupples LA, Felson DT \& Kiel DP 2000 Effect of dietary protein on bone loss in elderly men and women: The Framingham osteoporosis study. Journal of Bone and Mineral Research 15 2504-2512. (doi:10.1359/jbmr.2000.15.12.2504)

Hauschka P V, Lian JB, Cole DE \& Gundberg CM 1989 Osteocalcin and matrix Gla protein: vitamin K-dependent proteins in bone. Physiological Reviews 69 990-1047.

Heaney RP 2007 Bone health. American Journal of Clinical Nutrition 85 (Supplement) 300S-303S.

Heaney RP \& Holick MF 2011 Why the IOM recommendations for vitamin D are deficient. Journal of Bone and Mineral Research 26 455-457. (doi:10.1002/jbmr.328)

Heidelbaugh JJ 2013 Proton pump inhibitors and risks of mineral deficiency: evidence and clinical implications. Therapeutic Advances in Drug Safety 3 125-133. (doi:10.1177/2042098613482484)

Hita-Contreras F, Martínez-Amat A, Cruz-Díaz D \& Pérez-López FR 2015 Osteosarcopenic obesity and fall prevention strategies. Maturitas $\mathbf{8 0}$ 126-132. (doi:10.1016/j.maturitas.2014.11.009)

Holick MF, Siris ES, Binkley N, Beard MK, Khan A, Katzer JT, Petruschke RA, Chen E \& de Papp AE 2005 Prevalence of vitamin D inadequacy among postmenopausal North American women receiving osteoporosis therapy. Journal of Clinical Endocrinology and Metabolism 90 3215-3224. (doi:10.1210/jc.2004-2364)

Houston DK, Nicklas BJ, Ding J, Harris TB, Tylavsky FA, Newman AB, Lee JS, Sahyoun NR, Visser M \& Kritchevsky SB 2008 Dietary protein intake is associated with lean mass change in older, communitydwelling adults: the Health, Aging, and Body Composition (Health ABC) Study. American Journal of Clinical Nutrition 87 150-155.

Hubbard RE, O'Mahony MS, Calver BL \& Woodhouse KW 2008 Nutrition, inflammation, and leptin levels in aging and frailty. Journal of the American Geriatrics Society 56 279-284. (doi:10.1111/j.15325415.2007.01548.x)

Hughes VA, Frontera WR, Wood M, Evans WJ, Dallal GE, Roubenoff R \& Fiatarone Singh MA 2001 Longitudinal muscle strength changes in older adults: influence of muscle mass, physical activity, and health. Journals of Gerontology. Series A, Biological Sciences and Medical Sciences 56 B209-B217. (doi:10.1093/gerona/56.5.B209)

Hunter GR, Gower BA \& Kane BL 2010 Age related shift in visceral fat. International Journal of Body Composition Research 8 103-108.

Ilich JZ, Kelly OJ, Kim Y \& Spicer MT 2014a Low-grade chronic inflammation perpetuated by modern diet as a promoter of obesity and osteoporosis. Archives of Industrial Hygiene \& Toxicology $\mathbf{6 5}$ 139-148. (doi:10.2478/10004-1254-65-2014-2541)

Ilich JZ, Kelly OJ, Inglis JE, Panton LB, Duque G \& Ormsbee MJ 2014b Interrelationship among muscle, fat, and bone: connecting the dots on cellular, hormonal, and whole body levels. Ageing Research Reviews 15 51-60. (doi:10.1016/j.arr.2014.02.007)

Ilich JZ, Kelly OJ \& Inglis JE 2016 Osteosarcopenic Obesity Syndrome: What is it and how can it be identified and diagnosed? Current Gerontology and Geriatrics Research 2016 1-7. (doi:10.1155/2016/7325973)

Ilich JZ, Inglis JE, Kelly OJ \& McGee DL 2015 Osteosarcopenic obesity is associated with reduced handgrip strength, walking abilities, and balance in postmenopausal women. Osteoporosis International 26 2587-2595. (doi:10.1007/s00198-015-3186-y)

Ilich JZ, Brownbill RA \& Tamborini L 2003 Bone and nutrition in elderly women: protein, energy, and calcium as main determinants of bone mineral density. European Journal of Clinical Nutrition 57 554-565. (doi:10.1038/sj.ejcn.1601577)

Ilich JZ \& Kerstetter JE 2000 Nutrition in bone health revisited: a story beyond calcium. Journal of the American College of Nutrition 19 715-737. (doi:10.1080/07315724.2000.10718070)

Ilich JZ, Brownbill RA \& Coster DC 2010 Higher habitual sodium intake is not detrimental for bones in older women with adequate calcium intake. European Journal of Applied Physiology 109 745-755. (doi:10.1007/s00421-010-1412-z)

Institute of Medicine of the National Academies 2012 Dietary Reference Intakes for calcium and vitamin D. Report, National Academy of Sciences, USA.

Isidori AM, Strollo F, Morè M, Caprio M, Aversa A, Moretti C, Frajese G, Riondino G \& Fabbri A 2000 Leptin and aging: correlation with endocrine changes in male and female healthy adult populations of different body weights. Journal of Clinical Endocrinology and Metabolism 85 1954-1962. (doi:10.1210/jcem.85.5.6572)

Iwamoto I, Douchi T, Kosha S, Murakami M, Fujino T \& Nagata Y 2000 Relationships between serum leptin level and regional bone mineral density and bone metabolic markers in healthy women. Acta Obstetricia et Gynecologica Scandinavica 79 1060-1064.

Iwaniec UT \& Turner RT 2016 Influence of body weight on bone mass, architecture and turnover. Journal of Endocrinology 230 R115-R130. (doi:10.1530/JOE-16-0089).

JafariNasabian P, Inglis JE, Kelly OJ, Ilich JZ 2017 Osteosarcopenic obesity in women: Prevalence, impact and management challenges. International Journal of Women's Health 9 33-42. (doi:10.2147/IJWH. S106107)

Kalinkovich A \& Livshits G 2015 Sarcopenia - The search for emerging biomarkers. Ageing Research Reviews 22 58-71. (doi:10.1016/j. arr.2015.05.001)

Kalyani RR, Corriere M \& Ferrucci L 2014 Age-related and disease-related muscle loss: the effect of diabetes, obesity, and other diseases. Lancet 2 819-829. (doi:10.1016/S2213-8587(14)70034-8)

Kameda T, Mano H, Yuasa T, Mori Y, Miyazawa K, Shiokawa M, Nakamaru Y, Hiroi E, Hiura K, Kameda A, et al. 1997 Estrogen inhibits bone resorption by directly inducing apoptosis of the boneresorbing osteoclasts. Journal of Experimental Medicine 186 489-495. (doi:10.1084/jem.186.4.489)

Kanazawa I, Yamaguchi T, Yamamoto M, Yamauchi M, Yano S \& Sugimoto T 2009 Relationships between serum adiponectin levels versus bone mineral density, bone metabolic markers, and vertebral fractures in type 2 diabetes mellitus. European Journal of Endocrinology 160 265-273. (doi:10.1530/EJE-08-0642)

Karsenty G 2001 Leptin controls bone formation through a hypothalamic relay. Recent Progress in Hormone Research 56 401-415. (doi:10.1210/ rp.56.1.401)

Karsenty G \& Ferron M 2012 The contribution of bone to wholeorganism physiology. Nature 481 314-320. (doi:10.1038/ nature10763) 
Kelly OJ, Gilman JC, Kim Y \& Ilich JZ 2013 Long-chain polyunsaturated fatty acids may mutually benefit both obesity and osteoporosis. Nutrition Research 33 521-533. (doi:10.1016/j.nutres.2013.04.012)

Kelly OJ, Gilman JC, Kim Y \& Ilich JZ 2016 Micronutrient intake in the etiology, prevention and treatment of osteosarcopenic obesity. Current Aging Science 9 260-278.

Kelly OJ, Gilman JC, Kim Y \& Ilich JZ 2017 Macronutrient intake and distribution in the etiology, prevention and treatment of osteosarcopenic obesity. Current Aging Science 10 83-105.

Kim J, Lee Y, Kye S, Chung Y-S \& Lee O 2016 Association of serum vitamin D with osteosarcopenic obesity: Korea National Health and Nutrition Examination Survey 2008-2010. Journal of Cachexia, Sarcopenia and Muscle 8 259-266. (doi:10.1002/jcsm.12154)

Kim TN, Park MS, Ryu JY, Choi HY, Hong HC, Yoo HJ, Kang HJ, Song W, Park SW, Baik SH, et al. 2014 Impact of visceral fat on skeletal muscle mass and vice versa in a prospective cohort study: the Korean Sarcopenic Obesity Study (KSOS). PLoS One 9 e115407. (doi:10.1371/ journal.pone.0115407)

Kim Y, Kelly OJ, Ilich JZ 2013 Synergism of $\alpha$-linolenic acid, conjugated linoleic acid and calcium in decreasing adipocyte and increasing osteoblast cell growth. Lipids 48 787-802. (doi: 10.1007/s11745-0133803-5)

Kinyamu HK, Gallagher JC, Petranick KM \& Ryschon KL 1996 Effect of parathyroid hormone (hPTH[1-34]) infusion on serum 1,25-dihydroxyvitamin $\mathrm{D}$ and parathyroid hormone in normal women. Journal of Bone and Mineral Research 11 1400-1405. (doi:10.1002/jbmr.5650111005)

Kishida K, Funahashi T \& Shimomura I 2014 Adiponectin as a routine clinical biomarker. Best Practice \& Research Clinical Endocrinology \& Metabolism 28 119-130. (doi:10.1016/j.beem.2013.08.006)

Koroglu BK, Kiris F, Ersoy IH, Sutcu R, Yildiz M, Aksu O, Ermis F, Ersoy S \& Tamer MN 2011 Relation of leptin, adiponectin and insulin resistance to bone mineral density in type 2 diabetic postmenopausal women. Endokrynologia Polska 62 429-435.

Lang T, Cauley JA, Tylavsky F, Bauer D, Cummings S, Harris TB \& Health ABC Study 2010 Computed tomographic measurements of thigh muscle cross-sectional area and attenuation coefficient predict hip fracture: The health, aging, and body composition study. Journal of Bone and Mineral Research 25 513-519. (doi:10.1359/jbmr.090807)

Lazarus B, Chen Y, Wilson FP, Sang Y, Chang AR, Coresh J \& Grams ME 2016 Proton pump inhibitor use and the risk of chronic kidney disease. JAMA 176 238-246. (doi:10.1001/jamainternmed.2015.7193)

Lecke SB, Morsch DM \& Spritzer PM 2011 Leptin and adiponectin in the female life course. Brazilian Journal of Medical and Biological Research 44 381-387. (doi:10.1590/S0100-879X2011000500001)

Lee NK \& Karsenty G 2008 Reciprocal regulation of bone and energy metabolism. Trends in Endocrinology \& Metabolism 19 161-166. (doi:10.1016/j.tem.2008.02.006)

Lee B \& Shao J 2012 Adiponectin and lipid metabolism in skeletal muscle. Acta Pharmaceutica Sinica B 4 335-340.

Lee AJ, Hodges S \& Eastell R 2000 Measurement of osteocalcin. Annals of Clinical Biochemistry 37 432-446. (doi:10.1177/000456320003700402)

Lee S-G, Lee Y, Kim KJ, Lee W, Kwon OH \& Kim J-H 2013 Additive association of vitamin D insufficiency and sarcopenia with low femoral bone mineral density in noninstitutionalized elderly population: the Korea National Health and Nutrition Examination Surveys 2009-2010. Osteoporosis International 24 2789-2799. (doi:10.1007/s00198-013-2378-6)

Lewerin C, Johansson H, Lerner UH, Karlsson MK, Lorentzon M, BarrettConnor E, Smith U, Ohlsson C \& Mellström D 2015 High serum adiponectin is associated with low blood haemoglobin in elderly men: the Swedish MrOS study. Journal of Internal Medicine 278 68-76. (doi:10.1111/joim.12340)

Lindenmaier LB, Philbrick KA, Branscum AJ, Kalra SP, Turner RT \& Iwaniec UT 2016 Hypothalamic leptin gene therapy reduces bone

http://joe.endocrinology-journals.org

DOI: $10.1530 / J O E-16-0603$
(C) 2017 Society for Endocrinology Printed in Great Britain marrow adiposity in $o b / o b$ mice fed regular and high-fat diets. Frontiers in Endocrinology 7 110. (doi:10.3389/fendo.2016.00110)

Liu P \& Cai M 2017 Leptin influences healing in the sprague dawley rat fracture model. Medical Science Monitor 23 258-265. (doi:10.12659/ msm.899259)

Liu Y, Tang G, Tang R, Peng Y \& Li W 2010 Assessment of bone marrow changes in postmenopausal women with varying bone densities: magnetic resonance spectroscopy and diffusion magnetic resonance imaging. Chinese Medical Journal 123 1524-1527.

Liu P-Y, Hornbuckle LM, Panton LB, Kim J-S \& Ilich JZ 2012 Evidence for the association between abdominal fat and cardiovascular risk factors in overweight and obese African American women. Journal of the American College of Nutrition 31 126-132. (doi:10.1080/07315724.201 2.10720018)

Liu P-Y, Ilich JZ, Brummel-Smith K \& Ghosh S 2014 New insight into fat, muscle and bone relationship in women: determining the threshold at which body fat assumes negative relationship with bone mineral density. International Journal of Preventive Medicine $\mathbf{5}$ 1452-1463.

Luo X-H, Guo L-J, Xie H, Yuan L-Q, Wu X-P, Zhou H-D \& Liao E-Y 2006 Adiponectin stimulates RANKL and inhibits OPG expression in human osteoblasts through the MAPK signaling pathway. Journal of Bone and Mineral Research 21 1648-1656. (doi:10.1359/ jbmr.060707)

Maher RL, Hanlon J \& Hajjar ER 2014 Clinical consequences of polypharmacy in elderly. Expert Opinion on Drug Safety 13 57-65. (doi: 10.1517/14740338.2013.827660)

Mantzoros CS, Magkos F, Brinkoetter M, Sienkiewicz E, Dardeno TA, Kim S-Y, Hamnvik O-PR \& Koniaris A 2011 Leptin in human physiology and pathophysiology. American Journal of Physiolog, Endocrinology and Metabolism 301 E567-E584. (doi:10.1152/ajpendo.00315.2011)

Matkovic V, Ilich JZ, Andon MB, Hsieh LC, Tzagournis MA, Lagger BJ \& Goel PK 1995 Urinary calcium, sodium, and bone mass of young females. American Journal of Clinical Nutrition 62 417-425.

Mavros Y, Kay S, Simpson KA, Baker MK, Wang Y, Zhao RR, Meiklejohn J, Climstein M, O'Sullivan AJ, de Vos N, et al. 2014 Reductions in $\mathrm{C}$-reactive protein in older adults with type 2 diabetes are related to improvements in body composition following a randomized controlled trial of resistance training. Journal of Cachexia, Sarcopenia and Muscle 5 111-120. (doi:10.1007/s13539-014-0134-1)

McClaran SR, Babcock MA, Pegelow DF, Reddan WG \& Dempsey JA 1995 Longitudinal effects of aging on lung function at rest and exercise in healthy active fit elderly adults. Journal of Applied Physiology $\mathbf{7 8}$ 1957-1968.

Motyl KJ \& Rosen CJ 2012 The skeleton and the sympathetic nervous system: it's about time! Journal of Clinical Endocrinology and Metabolism 97 3908-3911. (doi:10.1210/jc.2012-3205)

Niedert KC 2005 Position of the American Dietetic Association: liberalization of the diet prescription improves quality of life for older adults in long-term care. Journal of the American Dietetic Association 105 1955-1965.

Ortman JM, Velkoff VA \& Hogan H 2014 An aging nation: the older population in the United States current population reports.

Oshima K, Nampei A, Matsuda M, Iwaki M, Fukuhara A, Hashimoto J, Yoshikawa H \& Shimomura I 2005 Adiponectin increases bone mass by suppressing osteoclast and activating osteoblast. Biochemical and Biophysical Research Communications 331 520-526. (doi:10.1016/j. bbrc.2005.03.210)

Pedersen BK \& Febbraio MA 2012 Muscles, exercise and obesity: skeletal muscle as a secretory organ. Nature Reviews 8 457-465. (doi:10.1038/ nrendo.2012.49)

Pereira-Santos M, Costa PRF, Assis AMO, Santos CAST \& Santos DB 2015 Obesity and vitamin D deficiency: a systematic review and metaanalysis. Obesity Reviews 16 341-349. (doi:10.1111/obr.12239)

Philbrick KA, Wong CP, Branscum AJ, Turner RT \& Iwaniec UT 2017 Leptin stimulates bone formation in ob/ob mice at doses having 
minimal impact on energy metabolism. Journal of Endocrinology 232 461-474. (doi:10.1530/JOE-16-0484)

Pires A, Martins P, Pereira AM, Marinho J, Vaz Silva P, Marques M, Castela E, Sena C \& Seiça R 2014 Pro-inflammatory triggers in childhood obesity: correlation between leptin, adiponectin and high-sensitivity C-reactive protein in a group of obese Portuguese children. Portuguese Journal of Cardiology 33 691-697. (doi:10.1016/j. repc.2014.04.004)

Pittenger MF, Mackay AM, Beck SC, Jaiswal RK, Douglas R, Mosca JD, Moorman MA, Simonetti DW, Craig S \& Marshak DR 1999 Multilineage potential of adult human mesenchymal stem cells. Science 284 143-147. (doi: 10.1007/s11745-013-3803-5)

Post JL \& Ilich JZ 2013 Controversies in vitamin D recommendations and its possible roles in nonskeletal health issues. Journal of Nutrition \& Food Sciences 3 213. (doi:10.4172/2155-9600.1000213)

Pradhan AD, Manson JE, Rifai N, Buring JE \& Ridker PM 2001 C-reactive protein, interleukin 6 , and risk of developing type 2 diabetes mellitus. JAMA 286 327-334. (doi:10.1001/jama.286.3.327)

Pray L, Boon C, Ann Miller E \& Pillsbury L 2010 Providing healthy and safe foods as we age: Workshop summary. Institude of Medicine of the National Academies.

Price PA \& Nishimoto SK 1980 Radioimmunoassay for the vitamin K-dependent protein of bone and its discovery in plasma. PNAS $\mathbf{7 7}$ 2234-2238. (doi:10.1073/pnas.77.4.2234)

Recker RR, Hinders S, Davies KM, Heaney RP, Stegman MR, Lappe JM \& Kimmel DB 1996 Correcting calcium nutritional deficiency prevents spine fractures in elderly women. Journal of Bone and Mineral Research 11 1961-1966. (doi:10.1002/jbmr.5650111218)

Reid IR 2008 Relationships between fat and bone. Osteoporosis International 19 595-606. (doi:10.1007/s00198-007-0492-z)

Reid IR \& Bolland MJ 2014 Calcium risk-benefit updated: New WHI analyses. Maturitas 77 1-3. (doi: 10.1016/j.maturitas.2013.10.003).

Reilly W \& Ilich JZ 2016 Vitamin B 12 deficiency and metformin use. Vitamins \& Minerals 5 e146. (doi:10.4172/2376-1318.1000e146)

Riggs BL, Melton LJ 3rd \& O'Fallon WM 1996 Drug therapy for vertebral fractures in osteoporosis: evidence that decreases in bone turnover and increases in bone mass both determine antifracture efficacy. Bone 18 197S-201S. (doi:10.1016/8756-3282(95)00502-1)

Rosen CJ \& Bouxsein ML 2006 Mechanisms of disease: is osteoporosis the obesity of bone? Nature Clinical Practice Rheumatology 2 35-43. (doi:10.1038/ncprheum0070)

Rousset S, Patureau Mirand P, Brandolini M, Martin J-F \& Boirie Y 2003 Daily protein intakes and eating patterns in young and elderly French. British Journal of Nutrition 90 1107-1115. (doi:10.1079/ BJN20031004)

Schaap LA, Pluijm SMF, Deeg DJH, Harris TB, Kritchevsky SB, Newman AB, Colbert LH, Pahor M, Rubin SM, Tylavsky FA, et al. 2009 Higher inflammatory marker levels in older persons: associations with 5-year change in muscle mass and muscle strength. Journal of Gerontology 64 1183-1189. (doi:10.1093/gerona/glp097)

Shapses SA \& Sukumar D 2012 Bone metabolism in obesity and weight loss. Annual Reviews of Nutrition 21 287-309. (doi: 10.1146/annurev. nutr.012809.104655)

Scheller EL \& Rosen CJ 2014 What's the matter with MAT? Marrow adipose tissue, metabolism, and skeletal health. Annals of the New York Academy of Sciences 1311 14-30. (doi:10.1111/nyas.12327)

Shea JL, King MTC, Yi Y, Gulliver W \& Sun G 2012 Body fat percentage is associated with cardiometabolic dysregulation in BMI-defined normal weight subjects. Nutrition, Metabolism and Cardiovascular Diseases 22 741-747. (doi:10.1016/j.numecd.2010.11.009)

Shin H, Liu P-Y, Panton LB \& Ilich JZ 2014 Physical performance in relation to body composition and bone mineral density in healthy, overweight, and obese postmenopausal women. Journal of Geriatric Physical Therapy 37 7-16. (doi:10.1519/JPT.0b013e31828af203)
Snellman G, Melhus H, Gedeborg R, Byberg L, Berglund L, Wemroth L \& Michaelsson K 2010 Determining vitamin D status: A comparison between commercially available assays. PLos ONE 5 e11555. (doi:10.1371/journal.pone0011555)

Stefanaki C, Peppa M, Boschiero D \& Chrousos GP 2016 Healthy overweight/obese youth: early osteosarcopenic obesity features. European Journal of Clinical Investigation 46 767-778. (doi:10.1111/eci.12659)

St-Onge M-P \& Gallagher D 2010 Body composition changes with aging: the cause or the result of alterations in metabolic rate and macronutrient oxidation? Nutrition 26 152-155. (doi:10.1016/j. nut.2009.07.004)

Strait JB \& Lakatta EG 2012 Aging-associated cardiovascular changes and their relationship to heart failure. Heart Failure Clinics 8 143-164. (doi:10.1016/j.hfc.2011.08.011)

Tang GY, Lv ZW, Tang RB, Liu Y, Peng YF, Li W \& Cheng YS 2010 Evaluation of MR spectroscopy and diffusion-weighted MRI in detecting bone marrow changes in postmenopausal women with osteoporosis. Clinical Radiology 65 377-381. (doi:10.1016/j. crad.2009.12.011)

Tieland M, Brouwer-Brolsma EM, Nienaber-Rousseau C, van Loon LJC \& De Groot LCPGM 2013 Low vitamin D status is associated with reduced muscle mass and impaired physical performance in frail elderly people. European Journal of Clinical Nutrition 67 1050-1055. (doi:10.1038/ejcn.2013.144)

Ubeda N, Achon M \& Varela-Moreiras G 2012 Omega 3 fatty acids in the elderly. British Journal of Nutrition 107 S137-S151. (doi:10.1017/ S0007114512001535)

Upadhyay J, Farr OM \& Mantzoros CS 2015 The role of leptin in regulating bone metabolism. Metabolism 64 105-113. (doi:10.1016/j. metabol.2014.10.021)

Visser M, Deeg DJH \& Lips P 2003 Low vitamin D and high parathyroid hormone levels as determinants of loss of muscle strength and muscle mass (sarcopenia): the Longitudinal Aging Study Amsterdam. Journal of Clinical Endocrinology and Metabolism 88 5766-5772. (doi:10.1210/ jc.2003-030604)

Wanner M, Martin BW, Autenrieth CS, Schaffner E, Meier F, Brombach C, Stolz D, Bauman A, Rochat T, Schindler C, et al. 2016 Associations between domains of physical activity, sitting time, and different measures of overweight and obesity. Preventive Medicine Reports $\mathbf{3}$ 177-184. (doi:10.1016/j.pmedr.2016.01.007)

Weiss LA, Barrett-Connor E, von Mühlen D \& Clark P 2006 Leptin predicts BMD and bone resorption in older women but not older men: the Rancho Bernardo study. Journal of Bone and Mineral Research 21 758-764. (doi:10.1359/jbmr.060206)

Wellen KE \& Hotamisligil GS 2005 Inflammation, stress, and diabetes. Journal of Clinical Investigation 115 1111-1119. (doi:10.1172/ JCI25102)

Williams GA, Wang Y, Callon KE, Watson M, Lin J, Lam JBB, Costa JL, Orpe A, Broom N, Naot D, et al. 2009 In vitro and in vivo effects of adiponectin on bone. Endocrinology 150 3603-3610. (doi:10.1210/ en.2008-1639)

Wilson PW \& Kannel WB 2002 Obesity, diabetes, and risk of cardiovascular disease in the elderly. American Journal of Geriatric Cardiology 11 119-123. (doi:10.1111/j.1076-7460.2002.00998.x)

Wood RJ 2008 Vitamin D and adipogenesis: new molecular insights. Nutrition Reviews 66 40-46. (doi:10.1111/j.1753-4887.2007.00004.x)

Yoon MJ, Lee GY, Chung J-J, Ahn YH, Hong SH \& Kim JB 2006 Adiponectin increases fatty acid oxidation in skeletal muscle cells by sequential activation of AMP-activated protein kinase, p38 mitogenactivated protein kinase, and peroxisome proliferator-activated receptor alpha. Diabetes 55 2562-2570. (doi:10.2337/db05-1322)

Zemel MB, Richards J, Milstead A \& Campbell P 2005 Effects of calcium and dairy on body composition and weight loss in African-American adults. Obesity Research 13 1218-1225. (doi:10.1038/oby.2005.144) http://joe.endocrinology-journals.org

DOI: 10.1530/JOE-16-0603
๑ 2017 Society for Endocrinology Printed in Great Britain
Published by Bioscientifica Ltd. 
Zhang P, Peterson M, Su GL \& Wang SC 2015 Visceral adiposity is negatively associated with bone density and muscle attenuation. American Journal of Clinical Nutrition 101 337-343. (doi:10.3945/ ajcn.113.081778)
Zheng B, Jiang J, Luo K, Liu L, Lin M, Chen Y \& Yan F 2015 Increased osteogenesis in osteoporotic bone marrow stromal cells by overexpression of leptin. Cell and Tissue Research 361 845-856. (doi:10.1007/s00441-015-2167-y)

Received in final form 7 April 2017

Accepted 25 April 2017

Accepted Preprint Published online 25 April 2017
๑) 2017 Society for Endocrinology Printed in Great Britain
Published by Bioscientifica Ltd.

Downloaded from Bioscientifica.com at 04/26/2023 10:03:48AM 